\title{
Spatial scales influence long-term response of herbivores to prescribed burning in a savanna ecosystem
}

Article in International Journal of Wildland Fire · January 2017

DOI: 10.1071 WF16152

5 authors, including:

Duncan M Kimuyu

Karatina University College

16 PUBLICATIONS 125 CITATIONS

Goshen College

SEE PROFILE

13 PUBLICATIONS 289 CITATIONS

SEE PROFILE

Truman P Young

University of California, Davis

215 PUBLICATIONS $\mathbf{8 , 1 0 1}$ CITATIONS

SEE PROFILE

Some of the authors of this publication are also working on these related projects:

Conifer regeneration contingent on interacting abiotic and biotic factors View project

Influences of climate and grazing on Polylepis forest regeneration and expansion View project 


\title{
Spatial scales influence long-term response of herbivores to prescribed burning in a savanna ecosystem
}

\author{
Duncan M. Kimuyu ${ }^{\mathrm{A}, \mathrm{B}, \mathrm{F}}$, Ryan L. Sensenig ${ }_{\mathrm{B}, \mathrm{C}}$, Robert M. Chira ${ }^{\mathrm{D}}$, \\ John M. Githaiga ${ }^{\mathrm{D}}$ and Truman P. Young $\mathrm{B}, \mathrm{E}$ \\ ${ }^{\text {A }}$ chool of Natural Resources and Environmental Studies, Karatina University, \\ PO Box 1957-10101, Karatina, Kenya. \\ ${ }^{B}$ Mpala Research Centre, PO Box 555-10400, Nanyuki, Kenya. \\ CDepartment of Biological Sciences, Goshen College, Goshen, IN 46526, USA. \\ ${ }^{D}$ School of Biological Sciences, University of Nairobi, PO Box 30197-00100, Nairobi, Kenya. \\ E Department of Plant Sciences, University of California, Davis, CA 95616, USA. \\ FCorresponding author. Email: dkimuyu@gmail.com
}

\begin{abstract}
Both wild and prescribed fire in savanna ecosystems influence habitat use by herbivores by creating or maintaining spatial and temporal heterogeneity in forage quality and vegetation cover. Yet little is known about how spatial scales influence long-term persistence of fire effects. We examined changes over a 6-year period in herbivore preference for experimentally burned patches that varied in spatial extent and grain. Avoidance for the burns by elephants and preference for the burns by impala and Grant's gazelle decreased significantly. For the rest of the species (zebra, eland, oryx, hartebeest, warthog and hare), there were no significant changes in preference for the burns. Changes in preference for the burned areas depended on the spatial extent and grain of the burn, with intermediate-size (9-ha) burns and large (8-ha) patchy burns being more preferred 6-7 years after fire. Grain, but not the spatial extent of the burned area, influenced changes in grass height. Fire resulted in a delayed reduced tree density irrespective of the spatial scale of the burn. Results of this study indicate that, depending on the scale of fire prescription, the impacts of fire on herbivores may last longer than previous studies suggest.
\end{abstract}

Additional keywords: dung survey, fire frequency, habitat heterogeneity, Laikipia, patchiness, tree cover.

Received 8 August 2016, accepted 16 February 2017, published online 4 April 2017

\section{Introduction}

Landscape heterogeneity is an important element in savanna ecosystems (Parr and Brockett 1999). It affects ecosystem function (Christensen 1997; Wiens 2002; Turner and Chapin 2005; Porensky and Veblen 2012) and to a great extent influences the persistence (Parr and Brockett 1999; du Toit 2003; Fuhlendorf et al. 2006; Fraterrigo et al. 2009; Fahrig et al. 2011; Miyashita et al. 2012), distribution (Morales and Ellner 2002) and movement patterns (Christensen 1997; Wiens 1997; Barraquand and Benhamou 2008) of herbivores in savanna landscapes. Hence, both natural processes and management interventions that create or maintain spatial and temporal heterogeneity are increasingly being promoted as ways to achieve biodiversity conservation goals and sustainability of ecosystem function (Benton et al. 2003; Fahrig et al. 2011; Kisel et al. 2011).

In most savanna ecosystems, fire has played a predominant role in creating and maintaining landscape heterogeneity, either by influencing pasture quality and productivity (Parr and Brockett 1999; Gureja and Owen-Smith 2002; Archibald et al. 2005; Sensenig et al. 2010) or by changing tree cover (Sankaran et al. 2005; Higgins et al. 2007; Bond 2008; Holdo et al. 2009). Fire increases forage quality by removing moribund herbage material and stimulating highly nutritious fresh growth with higher concentrations of some nutrients such as nitrogen, phosphorus, potassium, magnesium and copper (Van de Vijver et al. 1999; Laclau et al. 2002; Eby et al. 2014). The effects of fire on tree cover can be categorised as either immediate effects, such as heat-induced stress, damage or mortality on trees (first-order effects), or delayed effects resulting from post-fire interaction of direct fire effect and other factors, such as drought and herbivory (second-order effects) (Ryan and Elliot 2005; Reinhardt and Dickinson 2010). Although some of the effects of fire on forage quality are ephemeral, declining within a few months (Van de Vijver et al. 1999; Eby et al. 2014), the effects of fire on forage digestibility, leaf stem ratio and tree cover may persist for longer periods after fire (Van de Vijver et al. 1999).

Persistence of fire-induced heterogeneity likely depends on post-fire herbivory feedback. Burned areas generally attract high densities of herbivores owing to increased forage quality and greater predator visibility (Moe and Wegge 1997; Moe et al. 2009; Valeix et al. 2009; Sensenig et al. 2010; Eby et al. 2014). Herbivores thus attracted to burns may reinforce the initial impact of fire by maintaining pastures in short-cropped highly 
nutritious condition for a long time after fire or maintaining low tree and herbaceous cover, hence greater visibility. Although herbivore preference for burned areas is widely documented, most of the studies tend to be short-lived (Zavala and Holdo 2005; Sensenig et al. 2010; Eby et al. 2014; Green et al. 2015) and only a few studies report long-term dynamics of herbivore preference for burned areas. Understanding temporal dynamics in herbivore response to fire is essential for development of fire prescriptions in savanna ecosystems.

Individual species vary greatly in their habitat requirements; hence, it is reasonable to expect that long-term dynamics in herbivore response to burned areas vary across species. For example, species-specific differences in nutritional requirements, often driven by individual bodyweight and digestive physiology (hindgut versus foregut fermenters), could predict temporal dynamics in preference for burns. Also, because the spatial scales at which animals perceive landscape heterogeneity vary greatly across species (Ritchie 1998; Sensenig et al. 2010; Allred et al. 2011), we might expect diverse responses to burns at different scales. Two elements of spatial scale are important in understanding herbivores' response to landscape heterogeneity: the extent (the overall area that is burned) and grain (the size of individual burned patches). Both extent and grain may have important implications for herbivore attraction to (or avoidance of) previously burned patches, and hence can influence the post-fire grazing pressure and persistence of the initial effects of fire.

By implementing a unique set of controlled burns of different spatial extents (81, 9 and 1 ha) and grain (patchy and continuous) in areas with similar soil type and rainfall intensity, Sensenig (2007) demonstrated strong effects of spatial scale on attraction (or avoidance) of different herbivore species to burned areas within the first 2 years after burning. However, information regarding long-term persistence of these initial preference patterns for burned areas is generally lacking. We resurveyed these burns 6-7 years after fire: (i) to examine how preference patterns by different herbivore species had changed over time; (ii) to examine the effect of spatial scale on such preference patterns; and (iii) to examine correlations between tree cover and grass height and preference for the burned plots. The unique design of this experiment allowed us to test, for the first time, the influence of spatial scales on the long-term persistence of fire effects. This information could be useful in informing fire prescriptions to achieve a range of ecological and management goals.

\section{Materials and methods}

\section{Study area}

We conducted the present study on four ranches in Laikipia, Kenya: Mpala, Jessel, Segera and Ol Pejeta. All four ranches are located in the Laikipia Plateau on the dry leeward side of Mount Kenya at an altitude of $1800 \mathrm{~m}$ above sea level (see Fig. S1 available as online supplementary material). The area receives a weakly trimodal rainfall averaging 500-700 mm annually, with a distinct dry season in December to March. The common wildlife species on the four ranches include elephant (Loxodonta africana), giraffe (Giraffa camelopardalis), buffalo (Syncerus caffer), eland (Taurotragus oryx), plains zebra (Equus burchelli),
Grevy's zebra (Equus grevyi), Defassa waterbuck (Kobus ellipsiprymnus), oryx (Oryx beisa), hartebeest (Alcelaphus buselaphus), warthog (Phacochoerus africanus), Grant's gazelle (Gazella granti), impala (Aepyceros melampus), Thomson's gazelle (Eudorcas thomsonii), steinbuck (Raphicerus campestris) and hare (Lepus spp.). Management of the four ranches is similar in many ways, including integration of livestock production (mainly cattle (Bos indicus)) with wildlife conservation and application of prescribed burning. Our study plots were all located in homogeneous heavy clay (black cotton) vertisols. The overstorey in this system is dominated by Acacia drepanolobium trees, which make up $97 \%$ of the woody vegetation (Young et al. 1997). Minor woody species include Balanites aegyptica, Rhus natalensis and Acacia mellifera. The herbaceous layer is dominated by the perennial grass species Pennisetum stramineum, P. mezianum, Themeda triandra, Brachiaria lachnantha and Lintonia nutans, and common herbs include Aspilia pleuriseta, Commelina spp., Solanum incanum and Pseudognaphalium sp. (Porensky et al. 2013, suppl. 1).

\section{Experimental plots}

Data for the present study were collected from a series of experimental burn plots established in 2004 and 2005 as part of the Scale and Fire Ecology (SAFE) project that used fire to manipulate landscape heterogeneity at different spatial scales (Sensenig et al. 2010). A total of 18 plots were burned at the end of the dry season, just before the long rains, in February-March in 2004 and 2005. The 18 plots varied in both their extent (total area) and their grain (finest scale of resolution). Total burn extent varied at three levels: 1, 9 and 81 ha. Each size class was burned at two levels of grain: 'continuous' and 'patchy'. The patchy burns consisted of a quasi-random pattern of burned patches interspersed with unburned patches whereas the continuous burns consisted of a continuous block of burned area (Fig. S2). A complete set of treatments was implemented in 2004 and two or three replicates per treatment were added in 2005, except for the 81-ha patchy burn, which was not replicated owing to the rigorous burning protocol. In total, there were four 81-ha, four 9-ha and three 1-ha continuous burns, and one 81-ha, three 9-ha and three 1-ha patchy burns (Table S1). To maximise treatment independence, all burned plots were at least $1 \mathrm{~km}$ apart. See Sensenig et al. (2010) for more details.

\section{Data collection}

Dung counts were used to compare presence of herbivores in the burned plots and in the unburned matrix. Although there have been concerns about the use of dung counts as measures of mammal densities (Fuller 1991), including evidence for seasonality and habitat effects on decomposition rates (Vernes 1999; Nchanji and Plumptre 2001; Rivero et al. 2004), there is ample evidence from our study system (Augustine 2003; Augustine et al. 2003; Young et al. 2005; Riginos 2015) and elsewhere (Altendorf et al. 2001; Marques et al. 2001; Blake 2002; Rasmussen et al. 2005; Daniels 2006; Lunt et al. 2007) that dung counts are robust for comparing relative habitat use by large mammals within a species, habitat type and rainfall period. In the present study, dung counts were used as relative assays of animal presence, within a homogeneous habitat patch. For these 
purposes, it appears that dung counts are reliable measures in this ecosystem (Augustine et al. 2003; Young et al. 2005).

Dung counts were conducted along four $4 \mathrm{~m}$-wide fixed transects located at intervals of $20 \mathrm{~m}$ in 1-ha burns, $40 \mathrm{~m}$ in 9-ha burns and $200 \mathrm{~m}$ in 81-ha burns. To estimate wildlife presence in unburned areas near the treatments, two control transects were laid out perpendicular to each burned plot extending 200, 400 and $1200 \mathrm{~m}$ into the unburned matrix in the 1-, 9- and 81-ha burns respectively.

Dung was surveyed throughout each transect, recorded by species and subsequently crushed to avoid recounting in the next survey. Dung piles for all major herbivore species could be identified to species in the field, with two exceptions. The dung of cattle and buffalo could not be distinguished, and were counted together. The dung of plains and Grevy's zebras also could not be distinguished from each other and were grouped together as 'zebra'. However, plains zebra far outnumbered Grevy's zebra in the study system during the study period, so zebra dung counts are essentially plains zebra.

During the first surveys (in 2006, 1-2 years after the fire), four dung surveys were conducted (Sensenig et al. 2010), whose results were averaged in the present study. A single survey was conducted during the second round of surveys (in 2011, 6-7 years after the fire). To account for differences in dung accumulation time, we used preference index rather than absolute counts to compare the two survey periods (see Data analyses section).

Two of the 18 burned plots were excluded from analysis in this study because they had undergone significant managerial manipulations. One of these (1-ha continuous) had been reburned (accidental fire), whereas a cattle 'boma' (corral) had been constructed on the other one (9-ha continuous) (Table S1).

To test for correlations between tree density (index of tree cover) and grass height (index of grass cover and quality) and preference for the burns, we measured grass height and counted trees along transects in the burns and unburned areas. Previous work has demonstrated that grass height in this system is negatively correlated with crude protein and positively correlated with acid detergent fibre (ADF) (Sensenig 2007); hence, changes in grass height could be indicative of changes in forage quality (Arsenault and Owen-Smith 2002; Pavlů et al. 2006). Measurements on grass height were done at $15-\mathrm{m}$ intervals along each of the dung transects. For tree density, we counted all trees along a $10-\mathrm{m}$-wide belt transect running through the entire length of the burned plot and extending into the unburned matrix for an equal length. We also measured individual heights of each tree within the belt transects.

\section{Data analyses}

For each herbivore species, burn preference index was calculated as the ratio of dung density in burned areas divided by the dung density in both burned and unburned area. Preference index ranges from 0 to 1 , where 0 indicates complete avoidance, 1 indicates complete preference for burned areas, and 0.5 indicates equal use of burns and unburned areas. The use of preference indices instead of absolute dung count values helps to: (i) minimise seasonality effects such as differential dung decomposition; (ii) account for potential landscape variability in wildlife abundance; and (iii) allow comparisons to be made between herbivore species and across different sampling periods. To examine changes in preference of the burned areas across the two surveys, separate $\beta$ regression models (Ferrari and Cribari-Neto 2004) were fitted for each species using the 'betareg' package in $R$ (R Development Core Team 2009). Beta regression is a form of generalised linear models that assumes that the response variable is $\beta$-distributed and occurs in a continuous unit scale with a bounded range. To convert the preference values from open unit range (values occur between 0 and 1 with possibility of obtaining a value that is either 0 or 1 ) to a bounded unit range (values occur between 0 and 1 but no possibility of obtaining a value that is either 0 or 1$)$, the following rescaling transformation was applied: $y^{\prime}=[y(N-1)+s] / N$, where $s$ is a constant between 0 and 1 (serving as a prior from a Bayesian standpoint), and $N$ is the sample size (Smithson and Verkuilen 2006). To test for changes in preference over time, we first fitted a global model including interaction between species and survey period. We then tested for the species-specific changes by fitting separate models for each species. In both approaches, we included plot ID as a fixed effect to control for differences across plots. To test whether species-specific changes in preference for the burns over time were influenced by digestive physiology and bodyweight, we fitted separate models including interactions between digestive physiology, bodyweight and the survey period. We then tested for the interactive effects of spatial extent and grain of the burns on changes in preference for the burns over time. Finally, to identify factors driving preference for the burns, we built a candidate set of 432 generalised linear models with the following predictors and their first-order interactions: grass height, tree height class (trees taller than $0.8 \mathrm{~m}$ and trees shorter than $0.8 \mathrm{~m}$ ) and herbivore species. We then ranked these models using corrected Akaike Information Criterion $\left(\mathrm{AIC}_{\mathrm{C}}\right)$ to obtain the most parsimonious model (Burnham and Anderson 2002).

\section{Results}

A total of 131556 dung piles were counted during the initial four surveys completed 1-2 years after burning and 75536 during the single later survey completed 6-7 years after burning. Data for nine herbivores species were analysed, of which four were hindgut fermenters (elephant (3900 kg), zebra (275 kg), warthog $(69 \mathrm{~kg})$, and hare $(2 \mathrm{~kg}))$ and five were foregut fermenters (eland $(475 \mathrm{~kg})$, oryx $(205 \mathrm{~kg})$, Grant's gazelle $(55 \mathrm{~kg})$, hartebeest (144 kg), impala (53 kg) - bodyweights obtained from Sensenig et al. (2010)). Cattle (whose movements are largely dictated by herders) and buffalo (whose dung could not be distinguished from cattle dung) were not included in dung analyses. Thomson's gazelle and Defassa waterbuck were also excluded from analyses because they occurred in relatively low densities and were completely absent in at least $25 \%$ of all the burned plots. Giraffe and steinbuck, the only two pure browsers in this study system, were also excluded from analyses because this study was primarily focused on herbivores' response to fireinduced grass heterogeneity.

\section{Changes in preference for the burned areas}

Herbivores still preferred burned areas, even 6-7 years after fire. Overall preference for the burns decreased by only $3 \%$ (from 
0.61 to 0.59 ) between the initial surveys (1-2 years after the burns) and the second survey (6-7 years after the burn). However, this obscures greater species-specific responses, which included both significant increases and decreases in preference. After controlling for plot effect (different grain and spatial extent), preference for the burns by different species varied significantly between the two survey periods (Table S2a: species $\times$ survey period: $P=0.023$ ).

Three species (elephant, eland and warthog) avoided the burns (preference index less than 0.5) during the first surveys but only elephants avoided the burns during the second survey (Fig. 1). Even so, avoidance of the burns by elephant decreased by $38 \%$ between the first survey and the second survey (Table $\mathrm{S} 2 b: P=0.011)$. However, preference for the burns by Grant's gazelle decreased by $13 \%$ between the first and the second survey (Table $\mathrm{S} 2 b: P=0.028)$, and impala's preference for the burns tended to decrease (Table S2b: $P=0.073$ ). For the rest of species (zebra, eland, oryx, hartebeest, warthog and hare), we did not find significant changes in preference (or avoidance) for the burned areas (Table $\mathrm{S} 2 b$ ).

\section{Influence of bodyweight and digestive physiology}

Changes in preference (or avoidance) for the burns between the two survey periods depended on individual species bodyweight (Table S3a: bodyweight $\times$ survey period: $P=0.029$ ) but not significantly on digestive physiology (Table S3a, gut type $\times$ survey period: $P=0.17$ ). Although preference for the burns was inversely correlated with herbivore bodyweight

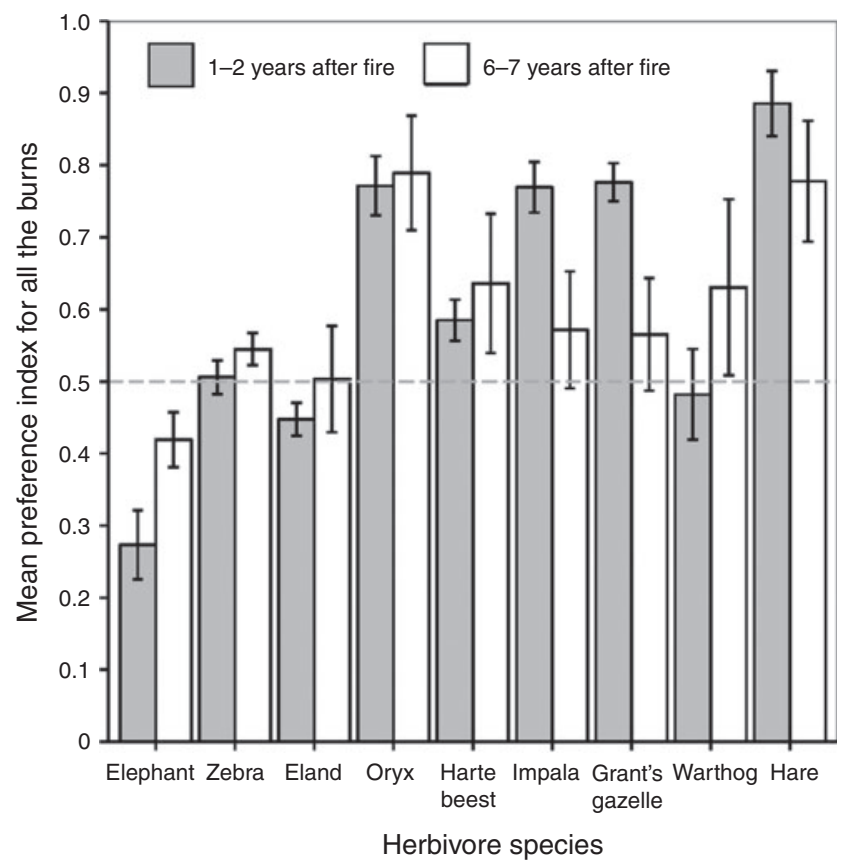

Fig. 1. Changes in individual species' preference for the burned areas between the initial sampling period (1-2 years after fire) and the second sampling period (6-7 years after fire). Values less than 0.5 indicate avoidance, values greater than 0.5 indicate preference, while 0.5 indicates equal presence in burned and unburned areas. Error bars represent standard error bars. during both survey periods (Fig. 2, Table $\mathrm{S} 3 b$ ), this relationship was stronger $1-2$ years after the burns (first survey; $r^{2}=0.74$; $Z=-4.25, P<0.001$ ) than $6-7$ years after the burns (second survey; $r^{2}=0.48 ; Z=-2.74, P=0.006$ ).

\section{Effects of spatial extent and grain of the burns}

Changes in overall preference for the burned areas between the first and the second survey period depended on both spatial extent and the grain of the burned plots (Table S4: survey $\times$ extent $\times$ grain: $Z=10.58, P=0.001)$. Preference for the largest patchy burns (81-ha patchy) increased, thus becoming the most preferred burn 6-7 years after fire, whereas preference for 81-ha continuous burns and all the intermediate-size burns (9-ha, both continuous and patchy) remained essentially unchanged (Fig. 3). The smallest burns (1-ha) shifted from being preferred to avoided, with a 21 and $18 \%$ reduction in preference index for patchy and continuous burns respectively. Overall, the change in herbivore preferences between 1-2 years and 6-7 years after fire was significantly positively correlated with burn diameter $\left(r^{2}=0.71 ; F_{1,4}=9.81, P=0.03\right)$.

\section{Differences in grass height and tree density between the burned and unburned areas}

Although the burned plots were initially set up in areas with similar tree density to the surrounding matrix (Sensenig 2007), the density of taller trees $(>0.8 \mathrm{~m})$ in burned areas decreased by $42 \%$ over the $6-7$-year period after the fire, resulting in significantly fewer trees in the burned than unburned areas (Fig. $4 a$ : $\left.F_{1,20}=12.28, P=0.002\right)$. However, the density of smaller trees (less than $0.8 \mathrm{~m}$ ) increased in burned areas relative to unburned areas, albeit not significantly (Fig. $4 b: F_{1,20}=0.41, P=0.53$ ). For both height classes, there were no significant effects of the spatial extent or grain of the burn tree density (Table S5).

Average grass height was significantly shorter in burned areas $(14.2 \pm 1.3 \mathrm{~cm})$ than unburned areas $(31.4+2.0 \mathrm{~cm})$ during the first survey $\left(F_{1,30}=51.42, P<0.001\right)$. During the

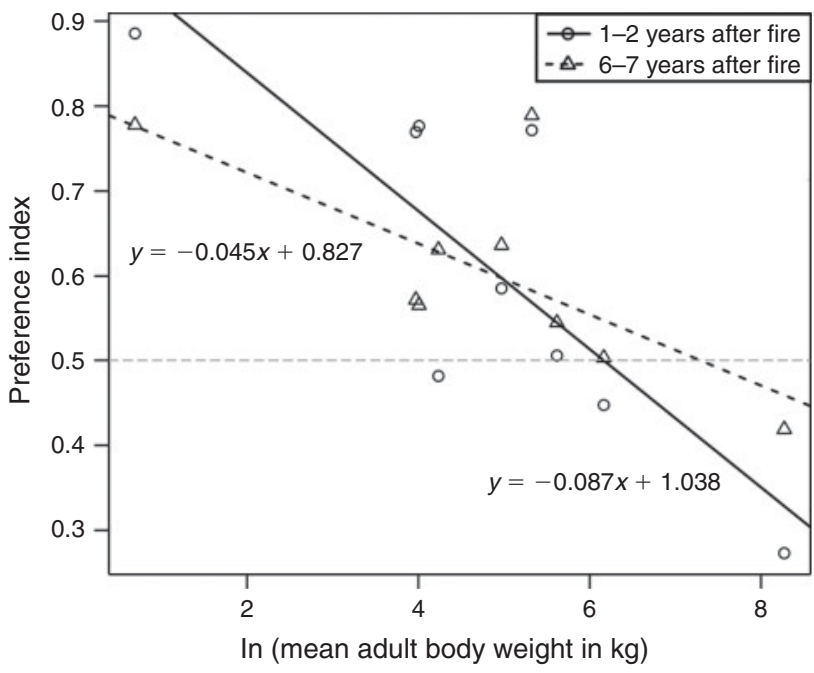

Fig. 2. Relationship between herbivores' bodyweight and their preference for the burns during the first sampling period and the second sampling period. Bodyweights were obtained from Sensenig et al. (2010). 
second survey, there were no longer significant differences $\left(F_{1,30}=0.14, P=0.71\right)$ between burned and unburned areas in grass height. Changes in grass height in the burned plots between the first and the second survey period depended on the grain (Table S6: grain $\times$ survey interaction: $F=4.74$, $P=0.04$ ), but not the spatial extent of the burns (Table S6: $F=0.52, P=0.60)$. For continuous burns, grass height increased significantly between the two survey periods (Fig. $5 a$

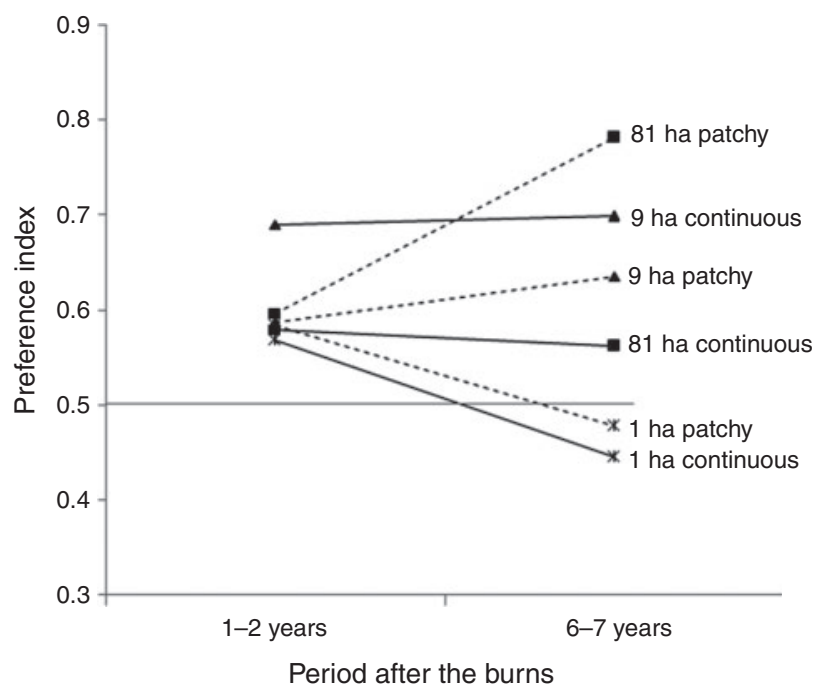

Fig. 3. Changes in overall preference of burns of different spatial extents (1-, 9- and 81-ha) and grain (continuous and patchy).

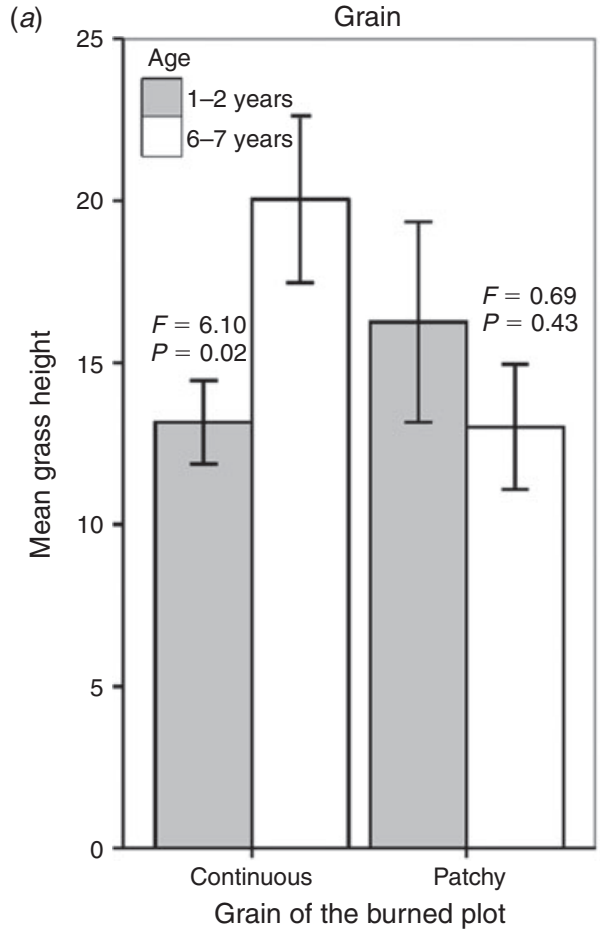

$F=6.10, P=0.02)$, but there were not significant changes in patchy burns (Fig. $5 b ; F=0.69, P=0.43$ ).

\section{Effects of trees and grass on preference for the burned plots}

From 432 candidate models testing the independent or interactive effects of grass height and tree density (trees shorter than $0.8 \mathrm{~m}$ and trees taller than $0.8 \mathrm{~m}$ ) on preference for the burns by individual species, the best-fitting model (Akaike weight $w i=0.51$ ) included only the main effects of grass height (Table S7). Overall preference for the burns was negatively correlated with grass height (ratio in burned vs unburned plots).

\section{Discussion}

This study provides evidence that herbivores' response to fireinduced heterogeneity persists for at least 6 years after fire. However, this response varied across individual species (in some systematic ways) and depended on the spatial scale (extent and grain) at which the burning was implemented. Intermediatesize (9-ha) burns and large (81-ha) patchy burns were most preferred 6-7 years after fire whereas small burns (1-ha both patchy and continuous) were the least preferred. Grain, but not the spatial extent of the burned area, influenced changes in grass height. Fire resulted in a delayed reduced tree density irrespective of the spatial scale of the burn.

\section{Long-term response of herbivores to fire}

Three mechanisms may explain the observed long-term preference by herbivores for burned sites. The first mechanism relates to herbivores maintaining burned areas as grazing lawns.

(b)

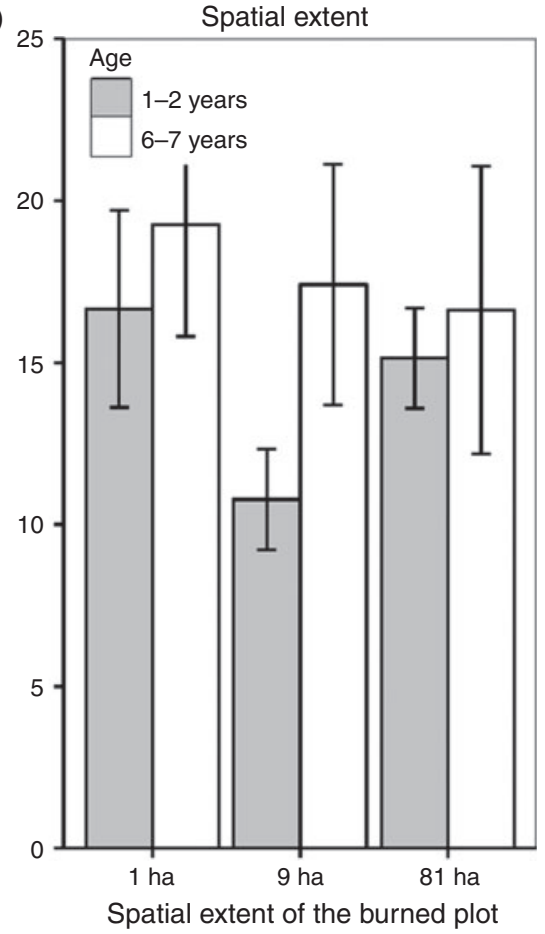

Fig. 4. Changes in average grass height between the first survey (1-2 years) and the second survey (6-7 years), in just the burned areas for burns of different ( $a$ ) grain (continuous and patchy); and $(b)$ spatial extent (1, 9 and $81 \mathrm{ha})$. Error bars represent standard error bars. 

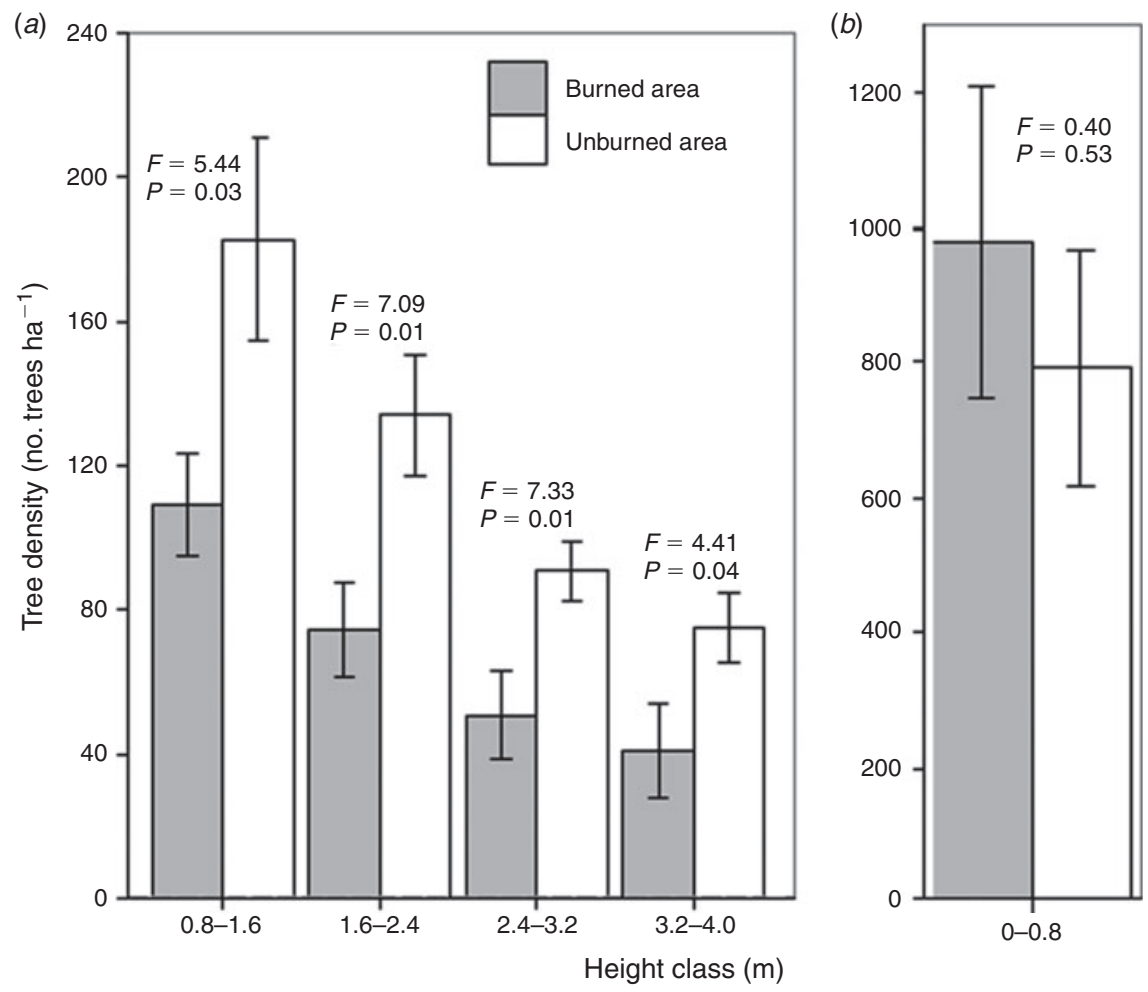

Fig. 5. Differences in the density of trees in burned areas relative to unburned areas for trees $(a)$ taller than $0.8 \mathrm{~m}$; and $(b)$ shorter than $0.8 \mathrm{~m}$. Error bars represent standard error bars.

Because burned areas attract large numbers of herbivores (Klop et al. 2007; Sensenig et al. 2010; Greene et al. 2012; Riginos et al. 2012; Eby et al. 2014), their preferential foraging in burns may maintain the herbaceous vegetation in short and nutritious state for a long time after fire. However, most studies on post-fire forage quality suggest that this increase in forage palatability is transient, lasting for only up to a year (Batmanian and Haridasan 1985; Van de Vijver et al. 1999; Green et al. 2015). Although the present study did not compare forage quality directly (i.e. crude protein or ADF) between burned and unburned sites 6-7 years after fire, a large decrease in the quality of post-fire regrowth was recorded within the first year after burning (Sensenig et al. 2010). Consistent with this, there were no significant differences in grass height between burned and unburned plots 6-7 years after fire. This suggests the observed long-term preference patterns are not likely to be primarily driven by forage quality.

A more plausible explanation for the observed long-term preference for the burned areas may be changes in vegetation cover. Fire modifies habitat structure either by directly reducing tree and shrub cover (Van Langevelde et al. 2003; Bond 2008; Staver et al. 2009) or indirectly through intensifying browsers' impact on trees in burned sites (Holdo et al. 2009; Staver et al. 2009; Gordijn and Ward 2014). In the current study system, browsers (particularly elephants) appear to interact synergistically with fire to reduce the densities of the mono-dominant Acacia drepanolobium trees (Okello et al. 2008; Wahungu et al. 2010; Wahungu et al. 2011; Pringle et al. 2015). In either case, there was a large $(>40 \%)$ reduction in the density of tall $(>0.8 \mathrm{~m})$ Acacia drepanolobium trees in the burned plots in the current study (Fig. 4a). As most of the large wild herbivores in the study system prefer more open areas (lower tree densities) owing to enhanced ability to detect predators (Augustine et al. 2011; Riginos 2015), it is likely that this reduction in tree cover is continuing to draw herbivores to previous burns long after the effect of fire on forage quality has faded.

Long-term attraction of herbivores could also relate to changes in forage composition after fire. Fire may facilitate the growth of palatable species (Greene et al. 2012) or increase species diversity (Savadogo et al. 2007) by creating open microsites for plant establishment (Morgan 1998; Pourreza et al. 2014), altering the soil environment (Marion et al. 1991; Neff et al. 2005) and triggering germination of seed-banking species (Keeley 1991; Brown and van Staden 1997; Crosti et al. 2006). This increase in floristic diversity may result in higher density and diversity of faunal assemblage (Elliott et al. 2011). In addition, herbivores attracted to the burns may also promote floristic diversity through intensive grazing or trampling, which creates open microsites in the same way as fire (Porensky et al. 2013). Although the present study did not investigate compositional dynamics of herbaceous vegetation, an increase in abundance of Themeda triandra with respect to three other dominant grasses in this system (Pennisetum mezianum, P. stramineum and Brachiaria lachnantha) was recorded earlier in the study (Sensenig 2007). Burning breaks seed dormancy in Themeda triandra, promoting its post-fire recruitment (Baxter and Van Staden 1994; Baxter et al. 1994). 
Although Themeda triandra has a lower crude protein content than the three other dominant grasses in this system (Sensenig 2007), it is a preferred grass species for herbivores (Novellie and Kraaij 2010).

\section{Influence of bodyweight and digestive physiology}

Extending the timeframe of previous studies (Wilsey 1996; Sensenig et al. 2010; Riginos et al. 2012; Eby et al. 2014), we found that the bodyweight of herbivores is a significant predictor of preference for burns even 6-7 years after fire. However, the observed decrease in the strength of the relationship between preference for the burns and bodyweight suggests a trend towards herbivores being less discriminating between burned and unburned areas over time (both positively and negatively).

Although small herbivores prefer the green flushes that emerge immediately after fire, and may exclusively feed in burned areas, large herbivores have to strike a balance between feeding on high-quality but limited forage in burns and feeding on readily available but less nutritious forage in unburned areas. Thus, as forage regrows towards preburn status and becomes less nutritious, the burns may become less attractive to small herbivores but more attractive (or less avoided) by large herbivores. This argument is also supported by the trend towards increase in preference for burns by hindgut fermenters (which require a higher quantity and can tolerate lower-quality forage for the same body size) and decrease in preference for foregut fermenters (which require a lower quantity but high-quality forage; Sensenig et al. 2010).

\section{Influence of spatial scale}

We found evidence in support of the idea that long-term attraction of herbivores to burned areas depends on the spatial scale of the fire treatment. There was a trend towards intermediate-sized (9-ha) burns being attractive to herbivores for the longest time (see Fig. 3). Also, long-term preference for burns with the largest spatial extent ( $81 \mathrm{ha}$ ) diverged depending on the grain, with patchy burns becoming more preferred over time and continuous burns not showing pronounced changes over time. The observed avoidance for small-size burns can be explained by the lack of adequate resources to support large densities of herbivores. Even though a substantial number of herbivores may visit small burns, a lower amount of dung in burned compared with unburned area suggests that herbivores spend disproportionately less time in the burns. Although the mechanism for this scale-mediated effect is not clear from this study, our findings support the idea that spatial scales, particularly spatial extent and grain, influence the response of large herbivores to heterogeneity in the landscape, and hence fireherbivory interactions.

\section{Conclusions}

Our results demonstrate that fire can exert lasting effects in the landscape and that the longevity of herbivore response to fire depends on the spatial scale at which fire is applied. Also, different herbivore species respond to burning differently, with some species avoiding burns generally, others preferring burns more during early successional stages and others preferring burns more during later successional stages. Future work should focus on elucidating the mechanism driving the observed long-term preference patterns. As a recommendation to managers interested in promoting herbivore diversity, it would be more beneficial implementing several interspersed burns of intermediate size than one big or small burn. However, these results are highly contingent on post-fire grazing and browsing intensity and therefore should be interpreted with caution.

\section{Acknowledgements}

We are grateful for the support from Mpala Research Center, Jessel Ranch, Segera Ranch and Ol Pejeta Conservancy. The following field assistants helped with the establishment of the study plots and the initial data collection: J. Ekiru, P. Etelej, J. Parkireuwa, D. Ranah and J. Mpaiyan. Special appreciation to J. Mpaiyan for his invaluable assistance in resurveying the plots. This research was supported by the Plant Sciences Department at the University of California (UC) - Davis; Jastro Shields Research Grants from UC-Davis; a National Science Foundation (NSF) Graduate Research Fellowship, an NSF Dissertation Improvement Grant and a Switzer Environmental Fellowship to R. L. Sensenig; and National Science Foundation grants (LTREB-BSR-03-16402, 08-16453 and 12-56034) to T.P. Young, C. Riginos, K.E. Veblen and K. Caylor.

\section{References}

Allred BW, Fuhlendorf SD, Engle DM, Elmore RD (2011) Ungulate preference for burned patches reveals strength of fire-grazing interaction. Ecology and Evolution 1, 132-144. doi:10.1002/ECE3.12

Altendorf KB, Laundré JW, López González CA, Brown JS (2001) Assessing effects of predation risk on foraging behavior of mule deer. Journal of Mammalogy 82, 430-439. doi:10.1644/1545-1542(2001) 082<0430:AEOPRO > 2.0.CO;2

Archibald S, Bond WJ, Stock WD, Fairbanks DHK (2005) Shaping the landscape: fire-grazer interactions in an African savanna. Ecological Applications 15, 96-109. doi:10.1890/03-5210

Arsenault R, Owen-Smith N (2002) Facilitation versus competition in grazing herbivore assemblages. Oikos 97, 313-318. doi:10.1034/ J.1600-0706.2002.970301.X

Augustine DJ (2003) Long-term, livestock-mediated redistribution of nitrogen and phosphorus in an East African savanna. Journal of Applied Ecology 40, 137-149. doi:10.1046/J.1365-2664.2003.00778.X

Augustine DJ, McNaughton SJ, Frank DA (2003) Feedbacks between soil nutrients and large herbivores in a managed savanna ecosystem. Ecological Applications 13, 1325-1337. doi:10.1890/02-5283

Augustine DJ, Veblen KE, Goheen JR, Riginos C, Young TP (2011) Pathways for positive cattle-wildlife interactions in semiarid rangelands. Smithsonian Contributions to Zoology 632, 55-71. doi:10.5479/ SI.00810282.632.55

Barraquand F, Benhamou S (2008) Animal movements in heterogeneous landscapes: identifying profitable places and homogeneous movement bouts. Ecology 89, 3336-3348. doi:10.1890/08-0162.1

Batmanian G, Haridasan M (1985) Primary production and accumulation of nutrients by the ground-layer community of cerrado vegetation of central Brazil. Plant and Soil 88, 437-440. doi:10.1007/BF02197500

Baxter BJM, Van Staden J (1994) Plant-derived smoke: an effective seed pre-treatment. Plant Growth Regulation 14, 279-282. doi:10.1007/ BF00024804

Baxter BJM, Van Staden J, Granger JE, Brown NAC (1994) Plant-derived smoke and smoke extracts stimulate seed germination of the fire-climax grass Themeda triandra. Environmental and Experimental Botany 34, 217-223. doi:10.1016/0098-8472(94)90042-6

Benton TG, Vickery JA, Wilson JD (2003) Farmland biodiversity: is habitat heterogeneity the key? Trends in Ecology \& Evolution 18, 182-188. doi:10.1016/S0169-5347(03)00011-9 
Blake S (2002) Forest buffalo prefer clearings to closed-canopy forest in the primary forest of northern Congo. Oryx 36, 81-86. doi:10.1017/ S0030605302000121

Bond WJ (2008) What limits trees in C4 grasslands and savannas? Annual Review of Ecology, Evolution, and Systematics 39, 641-659. doi:10.1146/ANNUREV.ECOLSYS.39.110707.173411

Brown NAC, van Staden J (1997) Smoke as a germination cue: a review. Plant Growth Regulation 22, 115-124. doi:10.1023/A:1005852018644

Burnham KP, Anderson DR (2002) 'Model selection and multimodel inference: a practical information-theoretic approach', 2nd edn. (Springer: New York)

Christensen N, Jr (1997) Managing for heterogeneity and complexity on dynamic landscapes. In 'The ecological basis of conservation'. (Eds STA Pickett, RS Ostfeld, M Shachak, GE Likens) pp. 167-186. (Springer: Florence, KY)

Crosti R, Ladd PG, Dixon KW, Piotto B (2006) Post-fire germination: the effect of smoke on seeds of selected species from the central Mediterranean basin. Forest Ecology and Management 221, 306-312. doi:10.1016/J.FORECO.2005.10.005

Daniels MJ (2006) Estimating red deer Cervus elaphus populations: an analysis of variation and cost-effectiveness of counting methods. Mammal Review 36, 235-247. doi:10.1111/J.1365-2907.2006.00091.X

du Toit JT (2003) Large herbivores and savanna heterogeneity. In 'The Kruger experience: ecology and management of savanna heterogeneity', 2nd edn. (Eds JT du Toit, KH Rogers, HC Biggs) pp. 292-309. (Island Press: Washington, DC)

Eby SL, Anderson TM, Mayemba EP, Ritchie ME (2014) The effect of fire on habitat selection of mammalian herbivores: the role of body size and vegetation characteristics. Journal of Animal Ecology 83, 1196-1205. doi: $10.1111 / 1365-2656.12221$

Elliott K, Harper C, Collins B (2011) Herbaceous response to type and severity of disturbance. In 'Sustaining young forest communities'. (Eds C Greenberg, B Collins, F Thompson III) Vol. 21, pp. 97-119. (Springer: New York)

Fahrig L, Baudry J, Brotons L, Burel FG, Crist TO, Fuller RJ, Sirami C, Siriwardena GM, Martin J-L (2011) Functional landscape heterogeneity and animal biodiversity in agricultural landscapes. Ecology Letters 14, 101-112. doi:10.1111/J.1461-0248.2010.01559.X

Ferrari S, Cribari-Neto F (2004) Beta regression for modelling rates and proportions. Journal of Applied Statistics 31, 799-815. doi:10.1080/ 0266476042000214501

Fraterrigo J, Pearson S, Turner M (2009) Joint effects of habitat configuration and temporal stochasticity on population dynamics. Landscape Ecology 24, 863-877. doi:10.1007/S10980-009-9364-6

Fuhlendorf SD, Harrell WC, Engle DM, Hamilton RG, Davis CA, Leslie DM (2006) Should heterogeneity be the basis for conservation? Grassland bird response to fire and grazing. Ecological Applications 16, 1706-1716. doi:10.1890/1051-0761(2006)016[1706:SHBTBF]2.0.CO;2

Fuller TK (1991) Do pellet counts index white-tailed deer numbers and population change? The Journal of Wildlife Management 55, 393-396. doi: $10.2307 / 3808966$

Gordijn P, Ward D (2014) Fire can suppress the development of macrophyllous thickets. African Journal of Range \& Forage Science 31, 147-160. doi:10.2989/10220119.2013.827587

Green DS, Roloff GJ, Heath BR, Holekamp KE (2015) Temporal dynamics of the responses by African mammals to prescribed fire. The Journal of Wildlife Management 79, 235-242. doi:10.1002/JWMG.827

Greene L, Hebblewhite M, Stephenson TR (2012) Short-term vegetation response to wildfire in the eastern Sierra Nevada: implications for recovering an endangered ungulate. Journal of Arid Environments 87, 118-128. doi:10.1016/J.JARIDENV.2012.06.001

Gureja N, Owen-Smith N (2002) Comparative use of burnt grassland by rare antelope species in a lowveld game ranch, South Africa. South African Journal of Wildlife Research 32, 31-38.
Higgins SI, Bond WJ, February EC, Bronn A, Euston-Brown DIW, Enslin B, Govender N, Rademan L, O'Regan S, Potgieter ALF, Scheiter S, Sowry R, Trollope L, Trollope WSW (2007) Effects of four decades of fire manipulation on woody vegetation structure in savanna. Ecology 88, 1119-1125. doi:10.1890/06-1664

Holdo RM, Holt RD, Fryxell JM (2009) Grazers, browsers, and fire influence the extent and spatial pattern of tree cover in the Serengeti. Ecological Applications 19, 95-109. doi:10.1890/07-1954.1

Keeley J (1991) Seed germination and life history syndromes in the California chaparral. Botanical Review 57, 81-116. doi:10.1007/ BF02858766

Kisel Y, McInnes L, Toomey NH, Orme CDL (2011) How diversification rates and diversity limits combine to create large-scale species-area relationships. Philosophical Transactions of the Royal Society of London. Series B, Biological Sciences 366, 2514-2525. doi:10.1098/ RSTB.2011.0022

Klop E, van Goethem J, de Iongh HH (2007) Resource selection by grazing herbivores on post-fire regrowth in a West African woodland savanna. Wildlife Research 34, 77-83. doi:10.1071/WR06052

Laclau J-P, Sama-Poumba W, Nzila JDD, Bouillet J-P, Ranger J (2002) Biomass and nutrient dynamics in a littoral savanna subjected to annual fires in Congo. Acta Oecologica 23, 41-50. doi:10.1016/S1146-609X (02)01132-3

Lunt N, Bowkett AE, Plowman AB (2007) Implications of assumption violation in density estimates of antelope from dung-heap counts: a case study on grey duiker (Sylvicapra grimmia) in Zimbabwe. African Journal of Ecology 45, 382-389. doi:10.1111/J.1365-2028.2006. 00724.X

Marion GM, Moreno JM, Oechel WC (1991) Fire severity, ash deposition, and clipping effects on soil nutrients in chaparral. Soil Science Society of America Journal 55, 235-240. doi:10.2136/SSSAJ1991. $03615995005500010040 \mathrm{X}$

Marques FFC, Buckland ST, Goffin D, Dixon CE, Borchers DL, Mayle BA, Peace AJ (2001) Estimating deer abundance from line transect surveys of dung: sika deer in southern Scotland. Journal of Applied Ecology 38, 349-363. doi:10.1046/J.1365-2664.2001.00584.X

Miyashita T, Chishiki Y, Takagi S (2012) Landscape heterogeneity at multiple spatial scales enhances spider species richness in an agricultural landscape. Population Ecology 54, 573-581. doi:10.1007/S10144-0120329-2

Moe SR, Rutina LP, Hytteborn H, du Toit JT (2009) What controls woodland regeneration after elephants have killed the big trees? Journal of Applied Ecology 46, 223-230. doi:10.1111/J.1365-2664.2008.01595.X

Moe SR, Wegge P (1997) The effects of cutting and burning on grass quality and axis deer (Axis axis) use of grassland in lowland Nepal Journal of Tropical Ecology 13, 279-292. doi:10.1017/S0266467400010452

Morales JM, Ellner SP (2002) Scaling up animal movements in heterogeneous landscapes: the importance of behavior. Ecology 83, 2240-2247. doi:10.1890/0012-9658(2002)083[2240:SUAMIH]2.0.CO;2

Morgan JW (1998) Importance of canopy gaps for recruitment of some forbs in Themeda triandra-dominated grasslands in south-eastern Australia. Australian Journal of Botany 46, 609-627. doi:10.1071/BT97057

Nchanji AC, Plumptre AJ (2001) Seasonality in elephant dung decay and implications for censusing and population monitoring in south-western Cameroon. African Journal of Ecology 39, 24-32. doi:10.1111/J.13652028.2001.00265.X

Neff JC, Harden JW, Gleixner G (2005) Fire effects on soil organic matter content, composition, and nutrients in boreal interior Alaska. Canadian Journal of Forest Research 35, 2178-2187. doi:10.1139/X05-154

Novellie P, Kraaij T (2010) Evaluation of Themeda triandra as an indicator for monitoring the effects of grazing and fire in the Bontebok National Park. Koedoe 52, 1-5. doi:10.4102/KOEDOE.V52I1.977

Okello BD, Young TP, Riginos C, Kelly D, O'Connor TG (2008) Shortterm survival and long-term mortality of Acacia drepanolobium after a 
controlled burn. African Journal of Ecology 46, 395-401. doi:10.1111/ J.1365-2028.2007.00872.X

Parr CL, Brockett BH (1999) Patch-mosaic burning: a new paradigm for savanna fire management in protected areas? Koedoe 42, 117-130. doi:10.4102/KOEDOE.V42I2.237

Pavlů V, Hejcman M, Pavlů L, Gaisler J, Nežerková P (2006) Effect of continuous grazing on forage quality, quantity and animal performance. Agriculture, Ecosystems \& Environment 113, 349-355. doi:10.1016/ J.AGEE.2005.10.010

Porensky L, Veblen K (2012) Grasses and browsers reinforce landscape heterogeneity by excluding trees from ecosystem hotspots. Oecologia 168, 749-759. doi:10.1007/S00442-011-2123-9

Porensky L, Wittman S, Riginos C, Young TP (2013) Herbivory and drought interact to enhance spatial patterning and diversity in a savanna understory. Oecologia 173, 591-602. doi:10.1007/S00442-013-2637-4

Pourreza M, Hosseini S, Sinegani A, Matinizadeh M, Alavai S (2014) Herbaceous species diversity in relation to fire severity in Zagros oak forests, Iran. Journal of Forestry Research 25, 113-120. doi:10.1007/ S11676-014-0436-3

Pringle RM, Kimuyu DM, Sensenig RL, Palmer TM, Riginos C, Veblen KE, Young TP (2015) Synergistic effects of fire and elephants on arboreal animals in an African savanna. Journal of Animal Ecology 84 1637-1645. doi:10.1111/1365-2656.12404

$\mathrm{R}$ Development Core Team (2009) 'R: a language and environment for statistical computing.' (R Foundation for Statistical Computing: Vienna, Austria) Available at http://www.R-project.org/ [Verified 21 February 2017)

Rasmussen HB, Kahindi O, Vollrath F, Douglas-Hamilton I (2005) Estimating elephant densities from wells and droppings in dried-out riverbeds. African Journal of Ecology 43, 312-319. doi:10.1111/J.13652028.2005.00580.X

Reinhardt ED, Dickinson MB (2010) First-order fire effects models for land management: overview and issues. Fire Ecology 6, 131-150. doi:10.4996/FIREECOLOGY.0601131

Riginos C (2015) Climate and the landscape of fear in an African savanna. Journal of Animal Ecology 84, 124-133. doi:10.1111/1365-2656.12262

Riginos C, Porensky LM, Veblen KE, Odadi W, Sensenig RL, Kimuyu DM, Keesing F, Wilkerson ML, Young TP (2012) Lessons on the relationship between livestock husbandry and biodiversity from the Kenya Long-term Exclosure Experiment (KLEE). Pastoralism: Research. Policy and Practice 2, 1-22. doi:10.1186/2041-7136-2-10

Ritchie M (1998) Scale-dependent foraging and patch choice in fractal environments. Evolutionary Ecology 12, 309-330. doi:10.1023/ A: 1006552200746

Rivero K, Rumiz D, Taber A (2004) Estimating brocket deer (Mazama gouazoubira and $M$. americana) abundance by dung pellet counts and other indices in seasonal Chiquitano forest habitats of Santa Cruz, Bolivia. European Journal of Wildlife Research 50, 161-167. doi:10.1007/S10344-004-0064-X

Ryan K, Elliot WJ (2005) Fire effects and soil erosion models. In 'Wildland fire in ecosystems: effects of fire on soils and water'. (Eds DG Neary, KC Ryan, LF DeBano) USDA Forest Service, Rocky Mountain Research Station, General Technical Report RMRS-GTR-42-Vol. 4, pp. 171-177. (Ogden, UT)

Sankaran M, Hanan NP, Scholes RJ, Ratnam J, Augustine DJ, Cade BS, Gignoux J, Higgins SI, Le Roux X, Ludwig F, Ardo J, Banyikwa F, Bronn A, Bucini G, Caylor KK, Coughenour MB, Diouf A, Ekaya W, Feral CJ, February EC, Frost PGH, Hiernaux P, Hrabar H, Metzger KL, Prins HHT, Ringrose S, Sea W, Tews J, Worden J, Zambatis N (2005) Determinants of woody cover in African savannas. Nature 438, 846-849. doi:10.1038/NATURE04070

Savadogo P, Tiveau D, Sawadogo L, Tigabu M (2007) 'Herbaceous species responses to long-term effects of prescribed fire, grazing and selective tree cutting in the savanna-woodlands of West Africa.' (Swedish University of Agricultural Sciences: Umea, Sweden)

Sensenig RL (2007) Spatial ecology of fire in an East African savanna: effects of burn size and patchiness on the foraging ecology of herbivores of varying body size. PhD dissertation, University of California, Davis

Sensenig RL, Demment MW, Laca EA (2010) Allometric scaling predicts preferences for burned patches in a guild of East African grazers. Ecology 91, 2898-2907. doi:10.1890/09-1673.1

Smithson M, Verkuilen J (2006) A better lemon squeezer? Maximumlikelihood regression with beta-distributed dependent variables. Psychological Methods 11, 54-71. doi:10.1037/1082-989X.11.1.54

Staver AC, Bond WJ, Stock WD, van Rensburg SJ, Waldram MS (2009) Browsing and fire interact to suppress tree density in an African savanna. Ecological Applications 19, 1909-1919. doi:10.1890/08-1907.1

Turner M, Chapin FS, III (2005) Causes and consequences of spatial heterogeneity in ecosystem function. In 'Ecosystem function in heterogeneous landscapes'. (Eds G Lovett, M Turner, C Jones, K Weathers) pp. 9-30. (Springer: New York)

Valeix M, Loveridge AJ, Chamaillé-Jammes S, Davidson Z, Murindagomo F, Fritz H, Macdonald DW (2009) Behavioral adjustments of African herbivores to predation risk by lions: Spatiotemporal variations influence habitat use. Ecology 90, 23-30.

Van de Vijver CADM, Poot P, Prins HHT (1999) Causes of increased nutrient concentrations in post-fire regrowth in an East African savanna. Plant and Soil 214, 173-185. doi:10.1023/A:1004753406424

Van Langevelde F, van de Vijver C, Kumar L, van de Koppel J, de Ridder N, van Andel J, Skidmore AK, Hearne JW, Stroosnijder L, Bond WJ, Prins HHT, Rietkerk M (2003) Effects of fire and herbivory on the stability of savanna ecosystems. Ecology 84, 337-350. doi:10.1890/0012-9658(2003)084[0337:EOFAHO]2.0.CO;2

Vernes K (1999) Pellet counts to estimate density of a rainforest kangaroo. Wildlife Society Bulletin 27, 991-996.

Wahungu GM, Mureu LK, Macharia PG (2010) Variability in survival and mortality of Acacia drepanolobium Sjøstedt following prescribed burning at Olpejeta Conservancy, Kenya. African Journal of Ecology 48, 744-750.

Wahungu GM, Mureu LK, Kimuyu DM, Birkett A, Macharia PG, Burton J (2011) Survival, recruitment and dynamics of Acacia drepanolobium Sjøstedt seedlings at Olpejeta Conservancy, Kenya, between 1999 and 2009. African Journal of Ecology 49, 227-233. doi:10.1111/J.13652028.2010.01254.X

Wiens J (1997) The emerging role of patchiness in conservation biology. In 'The ecological basis of conservation'. (Eds STA Pickett, RS Ostfeld, M Shachak, GE Likens) pp. 93-107. (Springer: Florence, KY)

Wiens J (2002) Central concepts and issues of landscape ecology. In 'Applying landscape ecology in biological conservation'. (Ed. K Gutzwiller) pp. 3-21. (Springer: New York)

Wilsey BJ (1996) Variation in use of green flushes following burns among African ungulate species: the importance of body size. African Journal of Ecology 34, 32-38. doi:10.1111/J.1365-2028.1996.TB00591.X

Young TP, Okello BD, Kinyua D, Palmer TM (1997) KLEE: a long-term multi-species herbivore exclusion experiment in Laikipia, Kenya. African Journal of Range \& Forage Science 14, 94-102. doi:10.1080/ 10220119.1997.9647929

Young TP, Palmer TM, Gadd ME (2005) Competition and compensation among cattle, zebras, and elephants in a semi-arid savanna in Laikipia, Kenya. Biological Conservation 122, 351-359. doi:10.1016/J.BIOCON. 2004.08.007

Zavala MA, Holdo RM (2005) Delayed effects of fire on habitat use by large herbivores in Acacia drepanolobium savanna. African Journal of Ecology 43, 155-157. doi:10.1111/J.1365-2028.2005.00552.X 